\title{
Grazing on diatoms by harpacticoid copepods: species-specific density-dependent uptake and microbial gardening
}

\author{
Marleen De Troch ${ }^{1, *}$, María Björk Steinarsdóttir ${ }^{3}$, Victor Chepurnov², \\ Emil Ólafsson ${ }^{4}$
}

\author{
${ }^{1}$ Marine Biology Section, and ${ }^{2}$ Protistology and Aquatic Ecology, Biology Department, Ghent University, Campus Sterre, \\ Krijgslaan 281 - S8, 9000 Gent, Belgium \\ ${ }^{3}$ Institute of Biology, University of Iceland, Sturlugata 7, 101 Reykjavík, Iceland \\ ${ }^{4}$ Department of Zoology, Stockholm University, 10691 Stockholm, Sweden
}

\begin{abstract}
Four common intertidal harpacticoid species (Paramphiascella fulvofasciata, Tigriopus brevicornis, Nitocra spinipes and Harpacticus obscurus) were offered pelagic diatoms (Phaeodactylum tricornutum) as food in laboratory experiments. To ensure generality we used copepod species originating from diverse habitats with different ecological characteristics. The diatoms were enriched in the stable carbon ${ }^{13} \mathrm{C}$ isotope to facilitate tracing in the harpacticoids. Uptake of diatoms was clearly species-specific and in general $P$. fulvofasciata was more efficient than the other species. We found significant uptake by $24 \mathrm{~h}$ of incubation for $T$. brevicornis. From $24 \mathrm{~h}$ onwards we found an increase for all 3 species. Species had similar $\delta^{13} \mathrm{C}$ values before and after starvation, indicating that labeled material was efficiently assimilated in their tissues. We tested whether diatom assimilation is density-dependent and this was true for 2 species ( $N$. spinipes and P. fulvofasciata) but not for the semi-pelagic T. brevicornis. Finally, a positive effect of faecal pellets on food uptake for the less mobile species was shown, indicating that microbial gardening occurs within benthic harpacticoids as it does for several other crustacean species.
\end{abstract}

KEY WORDS: Copepoda $\cdot$ Diatoms $\cdot$ Grazing $\cdot$ Assimilation $\cdot$ Stable isotopes

\section{INTRODUCTION}

Meiofauna represent an important link between microalgal primary production and higher trophic levels (e.g. Sogard 1984, De Troch et al. 1998, BuffanDubau \& Carman 2000). Harpacticoid copepods are an important part of the meiofauna, consuming primary production in planktonic, benthic and epiphytic communities (Hicks \& Coull 1983, Decho \& Fleeger 1988). Meiobenthic harpacticoids feed on a variety of food resources including epipelic or epiphytic diatoms, phytoflagellates, bacteria (either as aggregated cells or as detritus associates), fungi and yeasts, mucoid substances and ciliates (for overview see Hicks \& Coull 1983). In contrast to the direct use of detritus by macrofauna (Cammen 1980, Netto \& Galluci 2003), meiofauna rather use the microorganisms found on detritus (e.g. Montagna 1995, Widbom \& Frithsen 1995, Lillebo et al. 1999). The link between primary producers and higher trophic levels is therefore quite complex since it can be either direct or indirect. Transfer of primary production to higher trophic levels is direct when meiofauna feeds directly on the microalgae and/or bacteria and indirect if they feed on the secretions from the primary producers (e.g. Decho \& Moriarty 1990) or use micro-organisms that grow on the faecal pellets or the faecal pellets as food. Even if we know that they ingest these food items, their assimilation and contribution to the diet is less well known. 
While harpacticoid copepods (Crustacea) are rarely the dominant meiobenthic taxon in marine sediments, they almost always dominate in the gut contents of bottom or phytal feeding larval and juvenile fish (for review see Hicks \& Coull 1983). In spite of their potential importance in marine food webs, little is known about interspecific differences in copepod feeding strategies (e.g. Pace \& Carman 1996).

Radioactive and stable tracer techniques have been used in many experiments dealing with diatom grazing rates of meiobenthos (e.g. Decho \& Fleeger 1988, Demott 1995, Pace \& Carman 1996, Weiss et al. 1996, Ólafsson et al. 1999, Modig et al. 2000). Label has either been added directly into experimental units, i.e. sediment or water (Daro 1978, Montagna 1984, Rudnick 1989, Widbom \& Frithsen 1995), or by prelabeling diatom cultures prior to grazing (Decho 1986, Decho \& Fleeger 1988, Pace \& Carman 1996). Laboratory culturing of harpacticoids in combination with labeled primary producers as food (e.g. diatoms) offers opportunities to address specific questions of food uptake.

Several studies on the feeding ecology of meiofaunal organisms by means of tracer techniques have indicated taxon-specific uptake by several meiofaunal species (e.g. Ólafsson et al. 1999) and species-specific uptake of, e.g., diatoms among harpacticoid copepods (Decho 1986, Decho \& Fleeger 1988, Pace \& Carman 1996). Factors affecting the feeding mode (benthic or planktonic) of certain harpacticoid species include water-cover (Decho 1986) and tidal cycle (Decho 1988). Buffan-Dubau \& Carman (2000) found a diel feeding behaviour of some harpacticoids (Coullana sp., Microarthridion littorale, Pseudostenhelia wellsi) and ostracods with clear midday feeding peaks. The same study reported a grazer control of microalgal biomass as the diel variation of microalgal biomass appears to be influenced by meiofaunal grazing. Carman (1990) showed that ${ }^{14} \mathrm{C}$ bicarbonate uptake by copepods was almost exclusively due to grazing on labeled photoautotrophs. The observations of Pace \& Carman (1996) on 4 harpacticoids indicated that each copepod species exploits microalgal resources differently. Guisande et al. (2002) observed a food niche partitioning that may contribute to the coexistence of 4 calanoid copepod species, co-occurring in the water column. This sort of laboratory experiment helps to unravel the mechanisms that maintain high levels of density and diversity of copepod communities. However, many simple, although fundamental, questions remain largely unanswered.

By analysing the uptake of diatoms by harpacticoid species of different size and with different autecological characteristics (e.g. benthic vs. pelagic, swimmers vs. dwellers), the present study aimed to contribute to a better understanding of interspecific feeding strategies and their ecological implications.
We examined the following questions regarding relationships between autecology and feeding strategies:

(1) Does diatom uptake differ among harpacticoid species? In view of their different ecology (benthic vs. pelagic), one might expect that copepod species differ in their rate of diatom uptake. For example, mobile species or those spending substantial time in the water column are likely to utilise resources differently from less mobile or surface dependent species.

(2) Is uptake density-dependent in harpacticoids? What is the effect of crowding on diatom uptake? If either interspecific resource or interference competition for food sources occurs in harpacticoids, we expected that assimilation would be density-dependent, regardless of the species. Our expectations are that all copepod species would assimilate less diatoms as an effect of crowding independent of their ecology.

(3) Is uptake affected by faecal pellets, as a secondary effect of crowding? We hypothesised that faecal pellets and associated micro-organisms would enhance food assimilation of copepods and would differ among species depending on their ecological characteristics. We expected that species living intimately with food resources (i.e. benthic) would be more likely to use microbial gardening than species that are mobile and spend substantial time in the water column.

\section{MATERIALS AND METHODS}

Laboratory conditions and labeling technique. Four common intertidal harpacticoid copepod species were cultured in the laboratory: Tigriopus brevicornis (family Harpacticidae, found on the west-coast of Sweden in rock pools) Harpacticus obscurus (family Harpacticidae found on the north-coast of France on the brown alga Fucus serratus), Paramphiascella fulvofasciata (family Diosaccidae, found in Germany on intertidal mudflats) and Nitocra spinipes (family Ameiridae, found in the Baltic Proper, Sweden, on the green alga Cladophora glomerata). These copepods were selected in view of their different autecology: T. brevicornis is active in the water column while the others are (to different degrees) benthic species, dwelling in the sediment, although all are capable of swimming. T. brevicornis, $H$. obscurus, and $P$. fulvofasciata were cultured in artificial seawater of 31 to $32 \mathrm{psu}$ while $N$. spinipes was kept at $12 \mathrm{psu}$. All copepod cultures were stored in glass beakers of about 11 and regularly provided with a mixture of diatoms and detrital matter.

Diatoms were cultured in f2 medium (seawater with additional nutrients, Guillard 1975). For the experiments, the pelagic diatom Phaeodactylum tricornutum was cultured and enriched with ${ }^{13} \mathrm{C}$ by replacing $\mathrm{NaH}^{12} \mathrm{CO}_{3}$ with $\mathrm{NaH}^{13} \mathrm{CO}_{3}$ when preparing the f2 
medium. This labeled f2 medium was washed away and replaced by artificial seawater prior to the experiments. Copepods were sorted from the original stock cultures, starved for $24 \mathrm{~h}$ and washed in artificial seawater (to remove all food and faecal pellet particles) prior to placing them in Petri-plates with artificial seawater and labeled diatoms. In all experiments, a total of 6 million cells of $P$. tricornutum was offered as food. Based on counts of diatom cells in faecal pellets (M. De Troch unpubl. data) an average of 125000 diatom cells per copepod would correspond to food limitation.

Copepod and diatom cultures were kept at 15 to $18^{\circ} \mathrm{C}$ under a light regime of $12: 12 \mathrm{~h}$ light:dark. The experiments were conducted in small Petri-plates (diameter $=5.2 \mathrm{~cm}$, effective surface $=21.2 \mathrm{~cm}^{2}$ ) filled with $15 \mathrm{ml}$ of artificial seawater.

Experimental design. In all experiments Tigriopus brevicornis, Paramphiascella fulvofasciata and Nitocra spinipes were used. In order to accurately detect ${ }^{13} \mathrm{C} /{ }^{12} \mathrm{C}$ ratios in the tissue of the harpacticoids, a minimum of $15 \mu \mathrm{g} \mathrm{C}$ was analysed corresponding to 8,20 , 22 and 25 adults of $T$. brevicornis, $P$. fulvofasciata, $N$. spinipes and Harpacticus obscurus, respectively. As we had limited numbers of $H$. obscurus, this species was only included in Expt d (see below). For all experiments, each treatment was replicated 3 times and experimental units (Petri-plates) were placed randomly on a tray in the climate room.

Expt a-Temporal uptake of diatoms by harpacticoid copepods: The uptake of labeled diatoms by individual copepod species was followed at 4 time intervals, i.e. after 3, 24, 48 and $96 \mathrm{~h}$, resulting in 36 experimental units. In addition, time 0 was used to measure the natural carbon signature of the species, i.e. before feeding on the enriched material. At the end of each time interval, 3 replicates were randomly removed for each species and stored frozen for further analysis.

Expt b-Measurement of effective assimilation: To ascertain if the measurement of labeled diatoms in the copepods was a result of assimilation or the contents of guts, copepods were starved for $18 \mathrm{~h}$ after $96 \mathrm{~h}$ of feeding and compared to copepods that had not been starved.

Expt c-Effect of increased copepod density (crowding) on food uptake: To test the effect of crowding, 2 series were set up with the minimum number of copepods corresponding to $15 \mu \mathrm{g} \mathrm{C}$ (see above) (low density) and 4 times this number (high density), respectively. This corresponds to 3.7 and 15.1 ind. per $10 \mathrm{~cm}^{2}$ (Tigriopus brevicornis), 9.4 and 37.7 ind. per $10 \mathrm{~cm}^{2}$ (Paramphiascella fulvofasciata) and 10.4 and 41.4 ind. per $10 \mathrm{~cm}^{2}$ (Nitocra spinipes), respectively, for the low and high density series. For each treatment, copepods were left to feed for $96 \mathrm{~h}$. Altogether 18 experimental units were used, allowing 3 replicates per treatment and species.
Expt d-Effect of increased amount of faecal pellets: In addition to Expt c, 1 series was started with the minimum copepod density (see above) ('without faecal pellets' series). After $48 \mathrm{~h}$ of grazing, copepods were picked out and stored frozen until analysis. A second series ('with faecal pellets' series) was started by placing new individuals for another $48 \mathrm{~h}$ in the recovered Petri-plates. These Petri-plates contained both labeled diatoms and faecal pellets resulting from the first series of copepods and enabled us to test the effect of the presence of faecal pellets on uptake efficiency.

Analytic techniques and data treatment. At the end of each experiment, copepods were frozen in the original Petri-plates and stored for further analysis. Afterwards, copepods were hand-sorted, washed several times in deionised water and placed in tin capsules $(8 \times 5 \mathrm{~mm}$, pressed, standard weight) by means of a needle. The tin capsules containing the copepods and some water were dried in an oven at $60^{\circ} \mathrm{C}$ for $12 \mathrm{~h}$. Measurements of $\delta^{13} \mathrm{C}$ values were made using an isotope ratio mass spectrometer (type Europa Integra) at the UC Davis Stable Isotope Facility (University of California, USA).

In addition, as the copepod species were of different sizes, the $\delta^{13} \mathrm{C}$ values were initially recalculated (following Middelburg et al. 2000) taking into account individual biomass. For this, incorporation of ${ }^{13} \mathrm{C}$ is reflected as excess (above background) ${ }^{13} \mathrm{C}$ and is expressed as total uptake $(I)$ in $\mathrm{mg}^{13} \mathrm{C}$ ind. ${ }^{-1}$, calculated as the product of excess ${ }^{13} \mathrm{C}(E)$ and individual biomass (organic carbon). $E$ is the difference between the fraction ${ }^{13} \mathrm{C}$ of the control $\left(F_{\text {control }}\right)$ and the sample $\left(F_{\text {sample }}\right)$, where $F={ }^{13} \mathrm{C} /\left({ }^{13} \mathrm{C}+\right.$ $\left.{ }^{12} \mathrm{C}\right)=R /(R+1)$. The carbon isotope ratio $(R)$ was derived from the measured $\delta^{13} \mathrm{C}$ values as $R=\left(\delta^{13} \mathrm{C} / 1000+1\right) \times$ $R_{\mathrm{VPDB}}$ with $R_{\mathrm{VPDB}}=0.0112372$ as $\delta^{13} \mathrm{C}$ is expressed relative to Vienna Pee Dee Belemnite (VPDB). This total uptake was further standardised and expressed per unit carbon of copepod.

Differences in uptake among the various treatments were tested by means of 1- and 2-way analyses of variance (ANOVA) with Statistica sofware. A posteriori comparisons were carried out with the Tukey test using 95\% confidence limits. Prior to the ANOVA, Cochran's $C$-test was used to check the assumption of homoscedasticity.

\section{RESULTS}

\section{Temporal uptake of diatoms by harpacticoid copepods}

There was a significant increase in uptake of diatoms with time and this uptake varied among the 3 species (Tigriopus brevicornis, Nitrocra spinipes, Paramphiascella fulvofasciata) (2-way ANOVA, time: $\mathrm{p}<0.001$, 
species: $p<0.001$, interaction: $p<0.001$, Fig. 1A). No measurable uptake was found at $3 \mathrm{~h}$ (Tukey post-hoc test, $\mathrm{p}>0.05$ ) but there was a clear significant increase in uptake from $24 \mathrm{~h}$ onwards (Tukey test, $\mathrm{p}<0.001$, Fig. 1A). At $24 \mathrm{~h}$, only $T$. brevicornis was significantly enriched in ${ }^{13} \mathrm{C}$ (1-way ANOVA, $\left.\mathrm{p}<0.01, F=24.01\right)$. $T$. brevicornis and $N$. spinipes showed a relatively slow increase in uptake with time.

The diatom uptake by Paramphiascella fulvofasciata, on the other hand, was characterised by a steep increase after $24 \mathrm{~h}$. After $96 \mathrm{~h}$, P. fulvofasciata was about 5 times more enriched than the other 2 species (Fig. 1A). However, taking into account the biomass of each species, Fig. 1B illustrates that the largest species, i.e. Tigriopus brevicornis, took up the highest amount of carbon per individual. Standardisation of uptake per unit carbon of copepod (Fig. 1C) showed the same pattern as when uptake was expressed as $\delta^{13} \mathrm{C}$ (Fig. 1A).

\section{Measuring effective assimilation}

None of the 3 species showed a significant reduction in ${ }^{13} \mathrm{C}$ signal after $18 \mathrm{~h}$ of starvation, indicating that the excess of ${ }^{13} \mathrm{C}$ was a good measure of tissue assimilation. In terms of ${ }^{13} \mathrm{C}$ excess, Paramphiascella fulvofasciata was clearly more enriched than the other 2 species (2-way ANOVA, time: $p>0.05$, species: $p<0.001$, interaction $\mathrm{p}>0.05$, Fig. 2A). Total uptake per individual (Fig. 2B) showed again (see subsection above) a higher uptake by the largest species Tigriopus brevicornis. Total uptake per unit carbon of copepod (Fig. 2C) was very much comparable to the trend of $\delta^{13} \mathrm{C}$ values (Fig. 2A).

\section{Effect of crowding on diatom uptake by harpacticoid copepods}

Overall, there was a highly significant difference in diatom uptake among the species and between the density levels (2-way ANOVA, species: $p<0.001$, density: $p<0.01$, interaction: $p<0.05$, Fig. 3A). The Tukey post-hoc test showed that all 3 species differed from each other. For Nitocra spinipes (1-way ANOVA, p = 0.01 ) and Paramphiascella fulvofasciata (1-way ANOVA, $\mathrm{p}=0.05$ ) a 4 -fold increase in copepod density resulted in a lower per capita uptake of labeled diatoms (Fig. 3A). Tigriopus brevicornis showed no significant differences in uptake between both treatments (low vs. high copepod densities). However, in terms of total uptake per individual (Fig. 3B), as largest tested species $T$. brevicornis showed the highest uptake. The effect of crowding remained the same when uptake was standardised towards unit carbon of copepod (Fig. 3C).
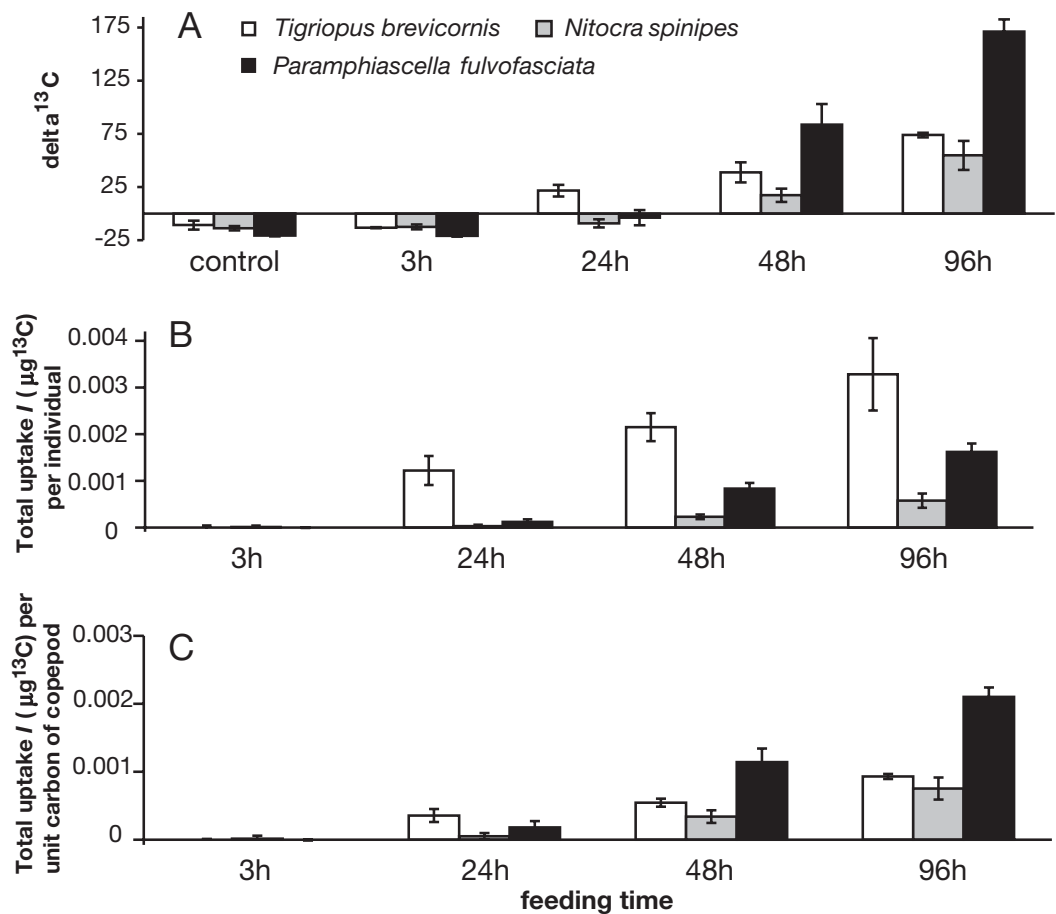

Fig. 1. Temporal diatom uptake (mean \pm SE) by 3 harpacticoid copepod species expressed as $(A) \delta^{13} C_{\text {, }}$ (B) total uptake per individual relative to individual biomass and $(\mathrm{C})$ total uptake per unit carbon of copepod

\section{Effect of faecal pellets on diatom uptake by harpacticoid copepods}

A positive effect of faecal pellets on diatom uptake was detected and this effect was species-specific (2-way ANOVA, species: $\mathrm{p}<0.01$, faecal pellets: $\mathrm{p}<0.001$, interaction: $p<0.001$, Fig. 4A). The presence of faecal pellets had a significant positive effect on the diatom uptake of Paramphiascella fulvofasciata (1-way ANOVA, $\mathrm{p}<0.001, F=175.5)$ and Nitocra spinipes (1-way ANOVA, $\mathrm{p}<0.001, F=$ 230.1). Despite visual observations of reworking and handling of faecal pellets by Harpacticus obscurus during the experiment, no significant effect of faecal pellets was found (1-way ANOVA, $\mathrm{p}=0.6, F=$ $0.4)$. In addition, no significant effect for Tigriopus brevicornis was detected (1-way ANOVA, $\mathrm{p}=0.6, F=0.4)$. As in the other experiments, the total uptake per individual was higher for $T$. brevicornis in both treatments. In addition, the uptake in terms of biomass was lower for $T$. brevicornis when faecal pellets were present, 

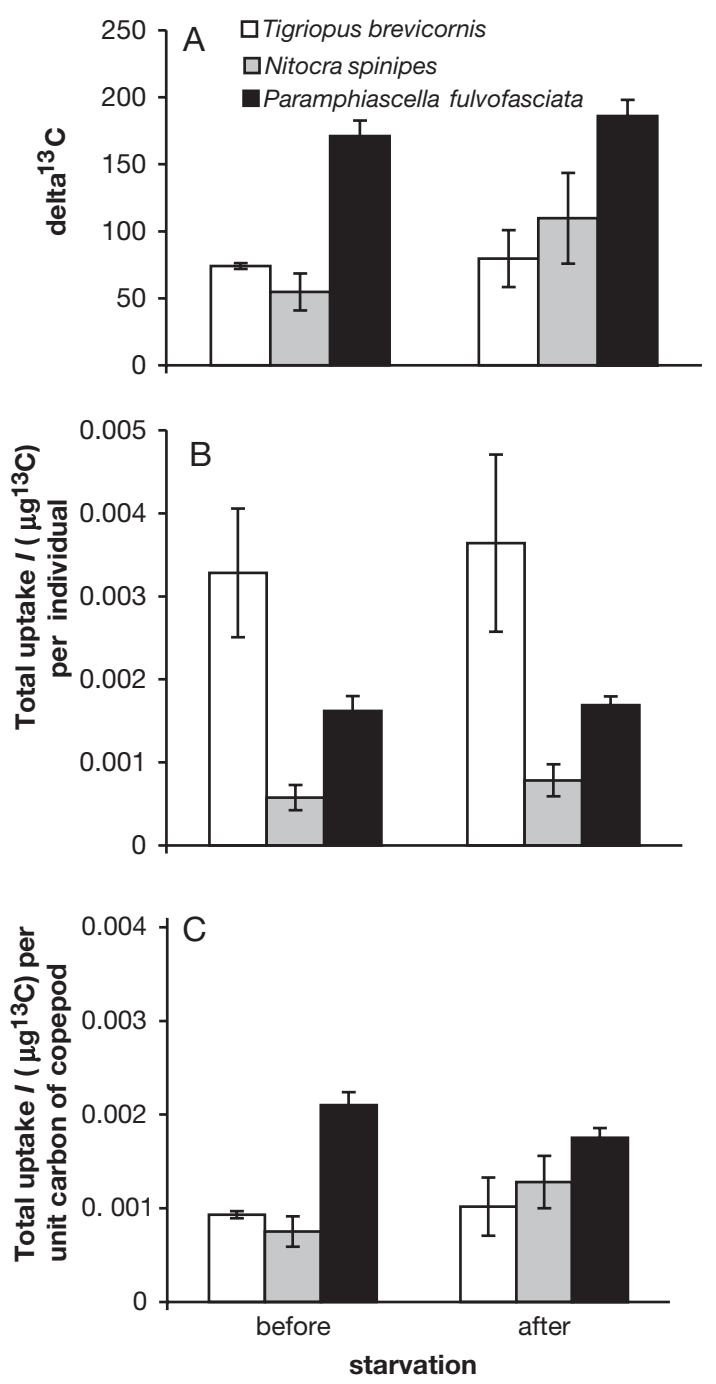

Fig. 2. Diatom uptake (mean $\pm \mathrm{SE}$ ) by 3 harpacticoid copepod species before and after starvation expressed as (A) $\delta^{13} \mathrm{C}$, (B) total uptake per individual relative to individual biomass and $(\mathrm{C})$ total uptake per unit carbon of copepod

although not significantly. The positive effect of faecal pellets remained significant for Nitocra spinipes (1way ANOVA, p < 0.01) when uptake was standardised towards unit carbon of copepod (Fig. 4C).

\section{DISCUSSION}

In the present study, the use of ${ }^{13} \mathrm{C}$ prelabeled diatoms allowed us to follow the grazing efficiency of harpacticoid copepods. As the complete organism (including its gut contents) was used to measure the uptake of enriched diatoms per time unit, the obtained results might refer to gut contents rather than to effective tissue assimilation of the diatoms by the copepods. If
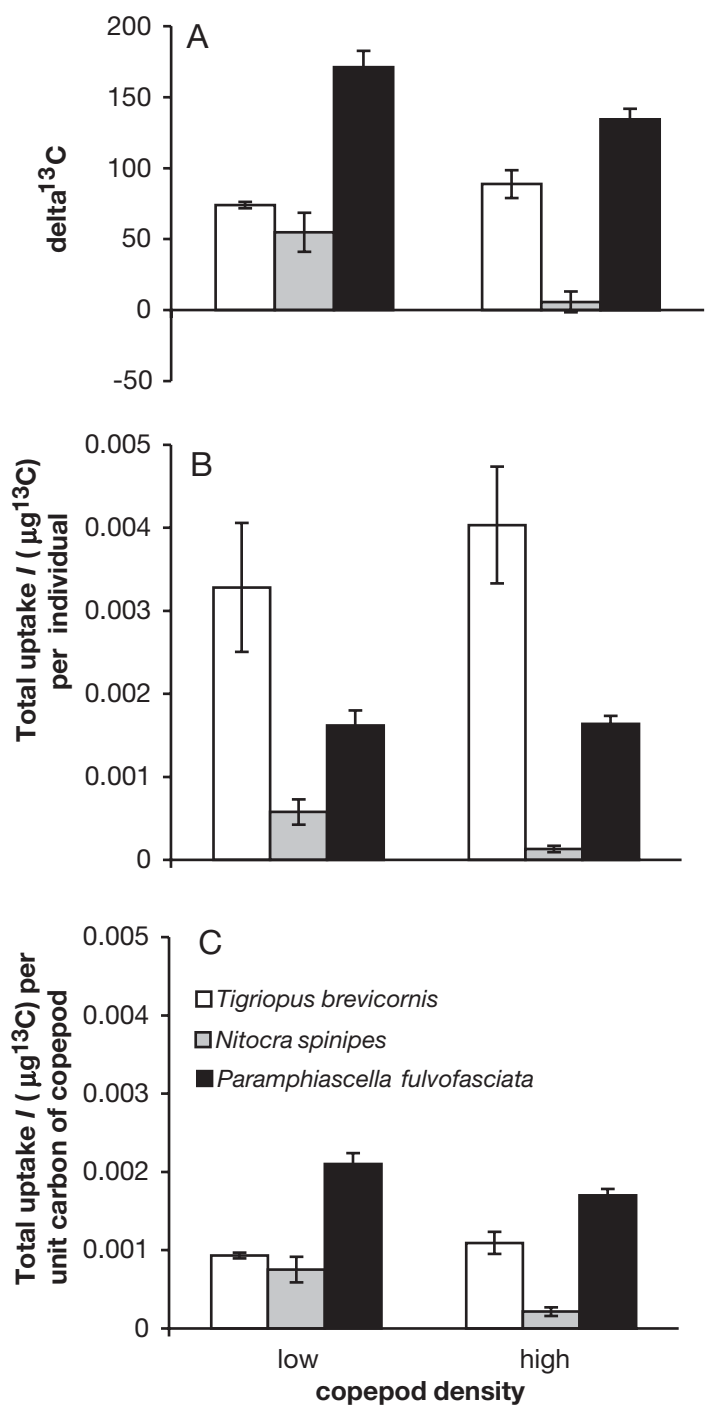

Fig. 3. Density-dependence of diatom uptake (mean $\pm \mathrm{SE}$ ) for 3 copepod species. Diatom uptake expressed as (A) $\delta^{13} \mathrm{C}$, (B) total uptake per individual relative to individual biomass and (C) total uptake per unit carbon of copepod. High density corresponds to 4 times the low density

this was the case, we expect a lower enrichment level for copepods with an empty gut. However, all species showed an increase or a stagnation of $\delta^{13} \mathrm{C}$, suggesting that the gut contents were of minor importance in the total ${ }^{13} \mathrm{C}$ measurements. From this, we can conclude that the overall set-up was suitable to give a good indication of the use of diatoms by harpacticoids. However, the uptake as it was measured in the present study is probably somewhat lower than absorption, as the 'fast metabolism' following the meal was lost and it is probably a little higher than true assimilation as the 'low metabolism' following assimilation was also lost.

Ólafsson et al. (1999) stated that prelabeled material is particularly useful in testing food selectivity, but that 

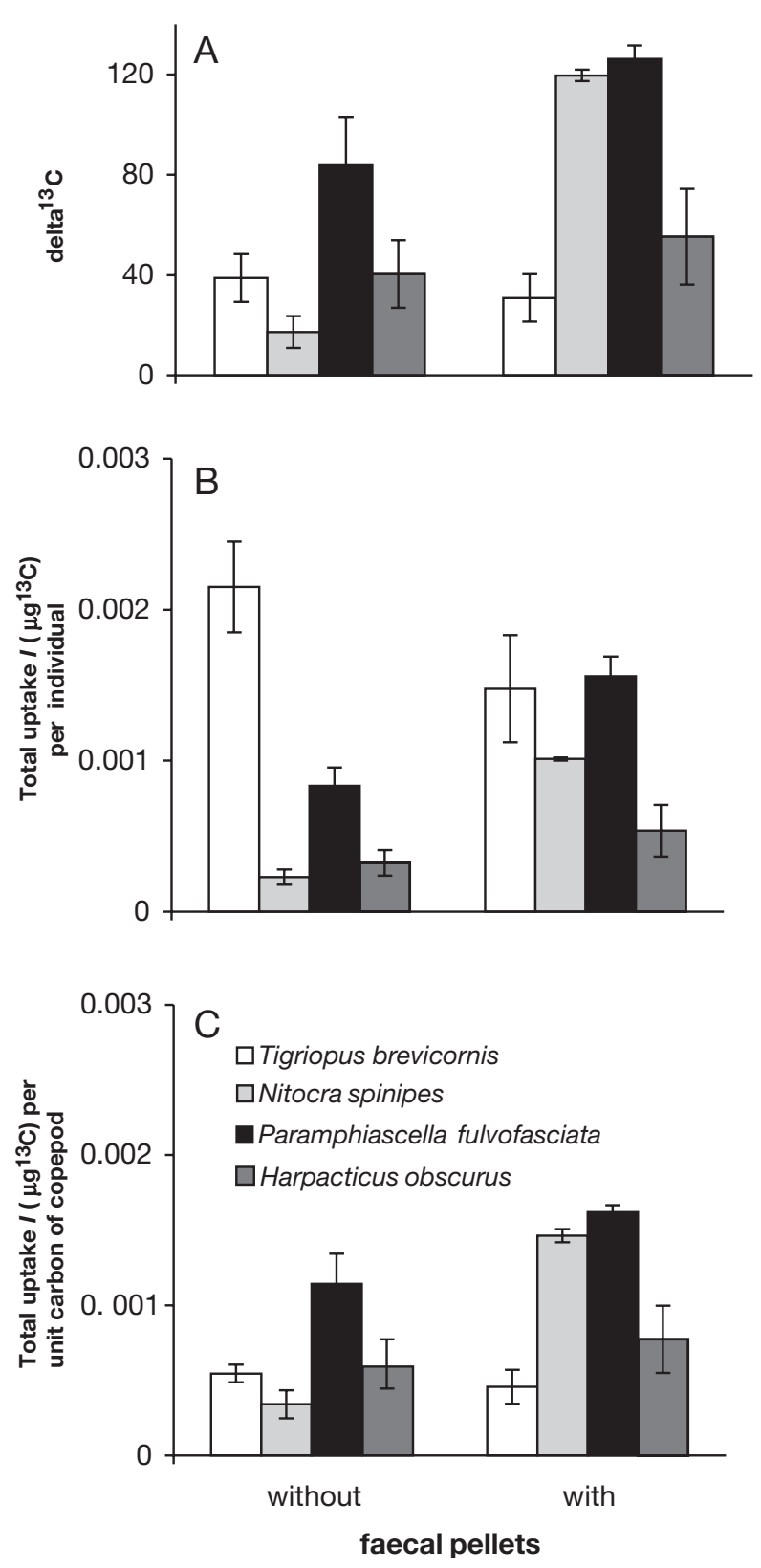

Fig. 4. Effect of faecal pellets on diatom uptake (mean \pm SE) for 4 harpacticoid copepod species. Diatom uptake expressed as (A) $\delta^{13} C_{\text {, }}$ (B) total uptake per individual relative to individual biomass and (C) total uptake per unit carbon of copepod

it might give inaccurate estimates of overall grazing rates in the field (Moens et al. 1999). A combination of natural-abundance isotope surveys and isotopeaddition experiments appears to be a powerful approach for investigating both average patterns and interspecific variability in resource exploitation (Carman \& Fry 2002). Pace \& Carman (1996) warned against possible differences between grazing behaviour in natural versus laboratory conditions.
Inherent in experimental work is the artificial nature of the set-up. In the present study, all experiments were conducted without any sediment in order to test the diatom uptake by different species under controlled conditions and with no interfering factors. One species (Tigriopus brevicornis) spends most time swimming in the water column and grazing at the bottom but is not a real sediment dweller like the other species involved in the experiment. As such, the presence of sediment would probably favour the diatom uptake by the sediment-dwellers. Copepod densities in the present study (between 4 and 40 ind. per $10 \mathrm{~cm}^{2}$ ) were very low in comparison to the natural conditions. In addition, as only 1 food concentration was considered in the experiments, the results may strongly depend on (1) the position of the tested concentration relative to functional responses and (2) species-specific differences of functional responses.

Finally, one should be aware that freezing of samples may result in leakage of label after thawing as was illustrated for cladocerans (Mourelatos et al. 1992) and nematodes (Moens et al. 1999). As suggested in both studies, sorting of organisms was done within $2 \mathrm{~h}$ of thawing in the present study to minimise possible leakage.

\section{Temporal uptake}

For the copepod species used (i.e. Nitocra spinipes, Paramphiascella fulvofasciata, Tigriopus brevicornis) temporal uptake of diatoms was mainly detectable from $24 \mathrm{~h}$ onwards as a clear enrichment in ${ }^{13} \mathrm{C}$ was detected. All copepod species showed an increase in ${ }^{13} \mathrm{C}$ in comparison with the control series, which corresponds to their natural ${ }^{13} \mathrm{C}$ signature. At $24 \mathrm{~h}$, only T. brevicornis showed a significant ${ }^{13} \mathrm{C}$ enrichment. The slope of the lines suggested that a stagnation phase was not reached after $4 \mathrm{~d}$ of grazing on the labeled diatoms.

A comparable temporal follow-up by Moens et al. (2002) showed a rapid initial uptake of prelabeled phytodetritus by nematodes, which mainly reflects ingestion of detritus. After $3 \mathrm{~h}$ the level of uptake remained constant up to $24 \mathrm{~h}$, followed by a sharp increase in ${ }^{13} \mathrm{C}$ after $72 \mathrm{~h}$. From this, Moens et al. (2002) suggested that labeling during longer incubations may result from different pathways, involving intermediate trophic steps between algal detritus and nematodes.

For nematodes, a quick initial uptake seems to be a general trend. Based on their in situ ${ }^{13} \mathrm{C}$-labeling experiment, Middelburg et al. (2000) found that nematodes became enriched after $1 \mathrm{~h}$ and ${ }^{13} \mathrm{C}$ level increased until Day 3. In contrast to our laboratory experiment, their in situ experiment involved a wider range of species being labeled, i.e. many diatoms, bacteria 
and even free label in the water. This can affect the final uptake as the scope to take up labeled material should be much greater in such experiments. In addition, the type of field experiments conducted by Middelburg et al. (2000) might be sensitive to patchiness of the microphytobenthos that is actually labeled (T. Moens pers. comm.). In summary, these laboratory and field results suggest that there might be an important difference in uptake efficiency of labeled material or at least in seize time between nematodes and copepods as we found a much later ${ }^{13} \mathrm{C}$ signal in harpacticoid copepods.

We found a clear interspecific difference in effective uptake as Paramphiascella fulvofasciata was 5 times more enriched than the other 2 species. Although $P$. fulvofasciata and Nitocra spinipes are of comparable size and carbon content $(P$. fulvofasciata about $0.83 \mathrm{~mm}$ and $15.6 \pm 0.6 \mu \mathrm{g} C_{i} N$. spinipes: 0.66 to $0.8 \mathrm{~mm}$ and $14.7 \pm 0.4 \mu \mathrm{g} \mathrm{C}$ ) but smaller and much lighter than Tigriopus brevicornis $(0.7$ to $1.2 \mathrm{~mm}$, $29.3 \pm 1.0 \mu \mathrm{g} \mathrm{C}), \quad$. fulvofasciata showed a higher enrichment. The increase in uptake in relation to time was much steeper for $P$. fulvofasciata from $24 \mathrm{~h}$ onwards, while the other 2 species showed a more gradual uptake. This can mean that this species takes more diatoms but has a lower assimilation efficiency or that it takes comparable amounts of diatoms but is more efficient in assimilating it. However, taking into account the individual biomass of each species, this stronger enrichment of $P$. fulvofasciata is not necessarily linked to a higher uptake of diatoms in absolute terms. The total uptake of carbon per individual followed a logical outcome with the largest animal (i.e. T. brevicornis) taking the highest amount of carbon. A possible explanation for this could be the origin of the cultured $P$. fulvofasciata as the stock culture was started from an intertidal mudflat population in contrast to the epiphytic habitat of the other species. Intertidal mudflats are characterised by a dense film of micro-organisms, often referred to as microbial biofilms (Decho 2000). These microbial biofilms are stabilised by specific extracellular polymeric secretions produced by diatoms (Decho 2000). P. fulvofasciata is probably well adapted to consume diatoms, which is reflected in its high uptake efficiency. Buffan-Dubau \& Carman (2000) illustrated that meiofaunal grazing (harpacticoids and ostracods) can even be so intensive that it may influence diel variation of microalgal biomass in mudflats.

In contrast, the gradual uptake by Nitocra spinipes and Tigriopus brevicornis may indicate that they use other resources that were not labeled in our experiments, e.g. bacteria. However, we assume that bacteria that occurred in the experimental units came from the breakdown of organic matter and as a conse- quence should have ${ }^{13} \mathrm{C}$ values similar to the diatoms because they presumably would use algal dissolved organic matter as a carbon source. Taking this into account, the gradual uptake by this species might be linked to culture conditions and the food source offered. Probably diatoms, and more specifically Phaeodactylum tricornutum, are not the favourite food source for these species. It might even have to do with prior feeding conditions where a mixture of diatoms and detrital matter was offered, which might be more suitable for these species.

\section{Effect of crowding on diatom uptake by harpacticoid copepods: evidence for intraspecific competition}

In case of effective assimilation, we were interested in the ecological implications of this food uptake. As resources were sufficient (although only 1 food source) in the experiments, we expected a certain level of competition, since the uptake of diatoms might be density-dependent.

The high grazing efficiency of Paramphiascella fulvofasciata was clearly affected by the presence of more individuals, although overall ${ }^{13} \mathrm{C}$ enrichment remained higher for $P$. fulvofasciata than for the other 2 harpacticoids. P. fulvofasciata and Nitocra spinipes showed a significantly lower uptake of diatoms at higher copepod densities. By definition, resource partitioning and resource competition imply that the partitioned resource is limiting (Begon et al. 1996). From this, we can conclude that at the food levels we used an intraspecific competition for diatoms occurred. Wenngren \& Ólafsson (2002) found for the amphipod Monoporeia affinis that intraspecific competition for food depends on the resource levels and is likely to be most intense under a regime of low to medium input of phytodetritus. Modig et al. (2000) observed a density-dependent uptake of phytodetritus for the ostracod Candona neglecta, where the uptake of ${ }^{14} \mathrm{C}$-labeled phytodetritus was stimulated at an intermediate ostracod density. The copepod densities used in the present study were relatively low compared to the natural ones. This suggests that intraspecific competition might be an important process in natural communities as we found a clear effect of crowding at low densities.

Future experiments should include even more individuals and additional combinations of different species in order to question interspecific competition. Pace \& Carman (1996) tested 4 different copepod species by means of ${ }^{14} \mathrm{C}$-radiotracer grazing experiments and gutpigment analyses and found interspecific differences in the use of microalgal resources, suggesting foodresource partitioning. 


\section{Secondary effect of crowding: the use of faecal pellets and associated micro-organisms}

Visual observations indicated that copepods, especially nauplii, reworked and probably fed on faecal pellets and associated micro-organisms ( $\mathrm{M}$. De Troch pers. obs.). Therefore, the effect of faecal pellets on uptake of harpacticoids as a possible secondary effect of crowding was tested.

For at least 2 species (Nitrocra spinipes, Paramphiascella fulvofasciata) an important increase in uptake was observed in the presence of more faecal pellets. As these 2 harpacticoid species are mainly benthic, this suggests that microbial gardening occurs within benthic harpacticoids as it does for several other organisms (Reise 1983, Robertson 1986, Skov \& Hartnoll 2002). Especially, $N$. spinipes was strongly positively affected by the presence of faecal pellets with almost 7 times higher enrichment in the presence of faecal pellets. In combination with the low grazing efficiency of $N$. spinipes (see Expt a) and the strong negative effect of crowding, we can conclude that $N$. spinipes is probably an inefficient grazer on the diatoms that were offered. On the other hand, $N$. spinipes seems to be using the microorganisms associated with faecal pellets. The dietary importance of heterotrophic bacteria associated with diatom cultures was analysed for Amonardia normani by Souza-Santos et al. (1999). They found a delay in larval development but survival was higher in an axenic diatom diet. Additional positive effects of micro-organisms have been referred to as 'gardening' (Fenchel 1978) and have been documented for nematodes (e.g. Riemann \& Schrage 1978). Hicks \& Graham (1979) described 'gardening' of selfelaborated mucous products by the phytal harpacticoid species Diarthrodes nobilis. Chandler \& Fleeger (1984, 1987) hypothesised that Pseudostenhelia wellsi 'gardens' microbial organisms on the walls of its mucus tube and feeds on these microbes. Decho \& Fleeger (1988) showed that both adults and nauplii of Nitocra lacustris ingest bacteria adhering to the outer mucus coating of the diatoms and probably ingest the diatom mucus itself. Decho \& Moriarty (1990) found that mucus-exopolymer secretions (EPS) of bacteria were ingested and utilised by Laophonte sp. (Harpacticoida, Laophonthidae). Absorption efficiencies were $>80 \%$ in the presence of other food sources, indicating that the exopolymer is potentially a highly labile $\mathrm{C}$ resource for this animal (Decho \& Moriarty 1990).

In these case-studies, the use of micro-organisms is clearly linked to self-elaborated mucus or mucous products. In contrast, the use of micro-organisms from faecal pellets or the re-use of faeces is unknown for harpacticoids to date. Noji et al. (1991), however, proved that coprorhexy (fragmentation of faecal mate- rial), coprochaly (loosen up faecal material) and coprophagy (ingestion of faecal material) in general plays an important role for planktonic calanoids. By reducing faecal pellets into smaller pieces, these processes increase the pelagic residence time of particles, promote substrate area for aerobic microbes and presumably enhance remineralisation of particulate organic matter. Gonzalez \& Smetacek (1994) illustrated that the cyclopoid Oithona ingested a significant amount of calanoid faecal pellets and this faecal matter accounts for about 20 to $30 \%$ of the daily carbon requirements of Oithona. A comparable phenomenon occurs in mangrove crabs that are known to fragment leaves during feeding and digestion (Malley 1978) with subsequent acceleration of microbial decay (Webster \& Benfield 1986).

In conclusion, the present study is the first to illustrate the importance of faecal pellets and associated micro-organisms for harpacticoid copepods. Moreover, several stable-isotope studies concluded that microphytobenthos is an important source of primary production for higher-level consumers (Peterson \& Howarth 1987, Sullivan \& Moncreiff 1990, Currin et al. 1995) but very little is known about how this production is transferred to higher trophic levels (BuffanDubau \& Carman 2000). When meiofaunal grazing is considered as a critical link between primary producers and higher trophic levels (Buffan-Dubau \& Carman 2000 ), in addition to direct uptake by grazing, the reuse of faecal pellets should be taken into account as a possible pathway.

Acknowledgements. The authors thank the director and the staff of the Askö Field Laboratory, where these experiments were conducted. M.D.T. acknowledges a postdoctoral fellowship and a long study stay at the University of Stockholm (Sweden) provided by the Fund for Scientific Research (FWOFlanders, Belgium). Subsequently, a FWO research project G.0313.04 was received to conduct future experiments. Rannís, The Icelandic Centre for Research, is acknowledged for financial support. H.-U. Dahms provided cultures of Paramphiascella fulvofaciata and E. Granéli cultures of Phaeodactylum tricornutum. M. Vincx and A. Ingólfsson gave valuable support to the study. K. Carman and 2 anonymous reviewers provided interesting comments in order to improve an earlier version of the manuscript.

\section{LITERATURE CITED}

Begon M, Harper JL, Townsend CR (1996) Ecology, 3rd edn. Blackwell Science, Oxford

Buffan-Dubau E, Carman KR (2000) Diel feeding behavior of meiofauna and their relationships with microalgal resources. Limnol Oceanogr 45:381-395

Cammen LM (1980) Ingestion rate: an empirical model for aquatic deposit feeders and detritivores. Oecologia 44: 303-310

Carman KR (1990) Mechanisms of uptake of radioactive 
labels by meiobenthic copepods during grazing experiments. Mar Ecol Prog Ser 68:71-83

Carman KR, Fry B (2002) Small-sample methods for $\delta^{13} \mathrm{C}$ and $\delta^{15} \mathrm{~N}$ analysis of the diets of marsh meiofaunal species using natural-abundance and tracer-addition isotope techniques. Mar Ecol Prog Ser 240:85-92

Chandler GT, Fleeger JW (1984) Tube-building by a marine meiobenthic harpacticoid copepod. Mar Biol 82:15-19

Chandler GT, Fleeger JW (1987) Facilitative and inhibitory interactions among estuarine meiobenthic harpacticoid copepods. Ecology 68:1906-1919

Currin CA, Newell SY, Paerl HW (1995) The role of standing dead Spartina alterniflora and benthic microalgae in salt marsh food webs: considerations based on multiple stable isotope analysis. Mar Ecol Prog Ser 121:99-116

Daro MH (1978) Simplified C-14 method for grazing measurements on natural planktonic populations. Helgol Wiss Meeresunters 31:241-248

Decho AW (1986) Water-cover influences on diatom ingestion rate by meiobenthic copepods. Mar Ecol Prog Ser 33: 139-146

Decho AW (1988) How do harpacticoid grazing rates differ over a tidal cycle? Field verification using chlorophyllpigment analyses. Mar Ecol Prog Ser 45:263-270

Decho AW (2000) Microbial biofilms in intertidal systems: an overview. Cont Shelf Res 20:1257-1273

Decho AW, Fleeger JW (1988) Ontogenetic shifts in the meiobenthic harpacticoid copepod Nitocra lacustris. Mar Biol 97:191-197

Decho AW, Moriarty DJW (1990) Bacterial exopolymer utilization by harpacticoid copepod: a methodology and results. Limnol Oceanogr 35:1039-1049

Demott WR (1995) Optimal foraging by a suspension-feeding copepod - responses to short-term and seasonal-variation in food resources. Oecologia 103:230-240

De Troch M, Mees J, Wakwabi EO (1998) Diets of abundant fishes from beach seine catches in seagrass beds of a tropical bay (Gazi Bay, Kenya). Belg J Zool 128:135-154

Fenchel TM (1978) The ecology of micro- and meiobenthos. Annu Rev Ecol Syst 9:99-121

Gonzalez HE, Smetacek V (1994) The possible role of the cyclopoid copepod Oithona in retarding vertical flux of zooplankton faecal material. Mar Ecol Prog Ser 113: 233-246

Guillard RL (1975) Culture of phytoplankton for feeding marine invertebrates. In: Smith WL, Chandley MH (eds) Culture of marine invertebrate animals. Plenum Press, New York, p 29-60

Guisande C, Maneiro I, Riviera I, Barreiro A, Pazos Y (2002) Estimation of copepod trophic niche in the field using amino acids and marker pigments. Mar Ecol Prog Ser 239: $147-156$

Hicks GRF, Coull BC (1983) The ecology of marine meiobenthic harpacticoid copepods. Oceanogr Mar Biol Annu Rev 21:67-175

Hicks GRF, Grahame J (1979) Mucus production and its role in the feeding-behavior of Diarthrodes nobilis (Copepoda, Harpacticoida). J Mar Biol Assoc UK 59:321-330

Lillebo AI, Flindt MR, Pardal MA, Marques JC (1999) The effect of macrofauna, meiofauna add microfauna on the degradation of Spartina maritima detritus from a salt marsh area. Acta Oecol 20:249-258

Malley DF (1978) Degradation of mangrove leaf litter by the tropical sesarmid crab Chiromanthes onychophorum. Mar Biol 49:377-386

Middelburg JJ, Barranguet C, Boschker HTS, Herman PT, Moens T, Heip CHR (2000) The fate of intertidal micro- phytobenthos carbon: an in situ ${ }^{13} \mathrm{C}$-labeling study. Limnol Oceanogr 45:1224-1234

Modig H, van de Bund WJ, Ólafsson E (2000) Uptake of phytodetritus by three ostracod species from the Baltic Sea: effects of amphipod disturbance and ostracod density. Mar Ecol Prog Ser 202:125-134

Moens T, Verbeeck L, Vincx M (1999) Preservation and incubation time-induced bias in tracer-aided grazing studies on meiofauna. Mar Biol 133:69-77

Moens T, Luyten C, Middelburg JJ, Herman PMJ, Vincx M (2002) Tracing organic matter sources of estuarine tidal flat nematodes with stable carbon isotopes. Mar Ecol Prog Ser 234:127-137

Montagna PA (1984) In situ measurement of meiobenthic grazing rates on sediment bacteria and edaphic diatoms. Mar Ecol Prog Ser 18:119-130

Montagna PA (1995) Rates of metazoan meiofaunal microbivory: a review. Vie Milieu 45:1-9

Mourelatos S, Rougier C, Lacroix G (1992) Radiotracer losses due to freezing in formalin of carbon-14-labelled cladocerans. Arch Hydrobiol 126:239-253

Netto SA, Gallucci F (2003) Meiofauna and macrofauna communities in a mangrove from the Island of Santa Catarina, South Brazil. Hydrobiologia 505:159-170

Noji TT, Estep KM, MacIntyre F, Norrbin F (1991) Image analysis of fecal material grazed upon by three species of copepods: evidence for coprorhexy, coprophagy and coprochaly. J Mar Biol Assoc UK 71:465-480

Ólafsson E, Modig H, van de Bund WJ (1999) Species specific uptake of radio-labelled phytodetritus by benthic meiofauna from the Baltic Sea. Mar Ecol Prog Ser 177:63-72

Pace MC, Carman KR (1996) Interspecific differences among meiobenthic copepods in the use of microalgal food sources. Mar Ecol Prog Ser 143:77-86

Peterson BJ, Howarth RW (1987) Sulfur, carbon and nitrogen isotopes used to trace organic matter flow in the saltmarsh estuaries of Sapelo Island, Georgia. Limnol Oceanogr 32: $1195-1213$

Reise K (1983) Biotic enrichment of intertidal sediments by experimental aggregates if the deposit-feeding bivalve Macoma balthica. Mar Ecol Prog Ser 12:229-236

Riemann F, Schrage M (1978) Mucus-trap hypothesis on feeding of aquatic nematodes and implications for biodegradation and sediment texture. Oecologia 34:75-88

Robertson AI (1986) Leaf-burying crabs: their influence on energy flow and export from mixed mangrove forests (Rhizophora spp.) in northeastern Australia. J Exp Mar Biol Ecol 102:237-248

Rudnick DT (1989) Time lags between the deposition and meiobenthic assimilation of phytodetritus. Mar Ecol Prog Ser 50:231-240

Skov MW, Hartnoll RG (2002) Paradoxical selective feeding on a low-nutrient diet: why do mangrove crabs eat leaves? Oecologia 131:1-7

Sogard SM (1984) Utilization of meiofauna as a food source by a grassbed fish, the spotted dragonet Callionymus pauciradiatus. Mar Ecol Prog Ser 17:183-191

Souza-Santos LP, Santos PJP, Castel J (1999) Development and population dynamics of Amonardia normani Brady reared on axenic and non-axenic diatoms. J Exp Mar Biol Ecol 235:167-182

Sullivan MJ, Moncreiff CA (1990) Edaphic algae are an important component of salt marsh food-webs: evidence from multiple stable isotope analysis. Mar Ecol Prog Ser 62:149-159

Webster JR, Benfield EF (1986) Vascular plant breakdown in freshwater ecosystems. Annu Rev Ecol Syst 18:567-694 
Weiss GM, McManus GB, Harvey HR (1996) Development and lipid composition of the harpacticoid copepod Nitocra spinipes reared on different diets. Mar Ecol Prog Ser 132: $57-61$

Wenngren J, Ólafsson E (2002) Intraspecific competition for food within and between year classes in the deposit-

Editorial responsibility: John Dolan,

Villefranche-sur-Mer, France feeding amphipod Monoporeia affinis-the cause of population fluctuations? Mar Ecol Prog Ser 240:205-213

Widbom B, Frithsen JB (1995) Structuring factors in a marine soft-bottom community during eutrophication - an experiment with radiolabeled phytodetritus. Oecologia 101: 156-168

Submitted: October 7, 2004; Accepted: January 25, 2005

Proofs received from author(s): April 4, 2005 